he realized that something must be done to end this state of confusion. In 1878, he proposed to the Canadian Institute in Toronto that the solution lay in dividing the globe into 24 time belts each of fifteen degrees of longitude, each belt to mark a difference of one hour in time. The Marquis of Lorne, at that time the Governor-General, submitted the proposal to the British Government, which, however, did not approve. The Tsar of Russia then initiated an international conference in Vienna in 1881 to discuss the matter. This led to a second conference in Washington in 1884 and the almost universal adoption of the proposal after the railways of Canada and the United States had already put standard time into use.

\section{Ramsay Memorial Fellowship}

THe following Ramsay Memorial fellowships for the year 1938-39 have recently been awarded: Dr. Vernon Hollis Booth, a British fellowship of $£ 300$, tenable for two years, at the University of Cambridge; Mr. Donald McNeil, a Glasgow fellowship of $£ 300$, tenable for two years at the University of Glasgow ; Dr. Alfred Epprecht, a Swiss fellowship of $£ 300$, tenable for one year, at the Imperial College of Science and Technology, London. The Trustees have renewed the following fellowships for a second year: Dr. A. E. Alexander (British fellow), at the University of Cambridge; Dr. E. de Salas (Spanish fellow), at University College, London; Dr. J. J. Hermans (Netherland fellow), at University College London; M. Jean Monvoisin (French fellow) at the Royal Institution, London; Mr. Hazime Oosaka (Japanese fellow), at University College, London; Dr. E. C. Stathis (Greek fellow), at the Imperial College of Science and Technology, London.

\section{Announcements}

Prof. H. Shapley, director of the Harvard College Observatory, Cambridge, Mass., has been elected a member in the Section of Astronomy, and Prince Louis-Victor de Broglie, of the Institut Poincaré, Paris, a member in the Section of Physics, of the Royal Swedish Academy of Sciences.

Prof. Emile Argand, professor of geology, mineralogy, petrography and palæontoology in the University of Neuchâtel, and Dr. E. A. Stensiö, director of the Department of Palæozoology in the Naturhistoriska Riksmuseum, Stockholm, have been elected foreign fellows of the Geological Society of London. Prof. H. von Eckermann, assistant professor of mineralogy and crystallography in the University of Stockholm, Prof. D. W. Johnson, professor of physiography in Columbia University, and Prof. A. A. Opik, professor of geology in the University of Esthonia, have been elected foreign correspondents.

Ar a meeting of the Royal Society of Edinburgh held on December 5, the president, Sir D'Arcy Thompson, showed and gave to the Society a copy of the billet of the corresponding meeting sixty years ago (December 16, 1878), when he had read a paper "On Ulodendron and Halonia" to the Society. This paper, communicated by Sir Wyville Thomson, was afterwards published by the Geological Society of Edinburgh, along with a plate drawn by another young man, known later on to all geologists as Benjamin Peach.

Honorary degrees have recently been conferred by the University of Paris on the following: Prof. Szent-Györgi, professor of medical chemistry in the University of Szeged faculty of medicine, Dr. S. P. L. Sörensen, director of the chemical section of the Carlsberg Laboratory, Copenhagen, and Dr. Karrer, director of the Institute of Chemistry, University of Zurich.

Prof. Jules Bordet, director of the Pasteur Institute of Brussels, was presented with the Grand Cross of the Legion of Honour at the opening meeting of the Congress of the Association of French-speaking Microbiologists.

The Sir Frederick Hobday Presentation Fund has

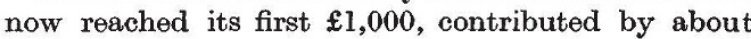
850 subscribers. The committee has decided to continue its work in order to obtain the amount necessary for the object which Sir Frederick Hobday had in view, namely, the endowment of a chair of comparative medicine. Subscriptions should be sent to the honorary secretary, Mr. E. T. Cox, 3 St. John's Avenue, S.W.15.

The Annual Conference of the Geographical Association will be held at the London School of Economics on January 3-6, 1939, under the presidency of Sir Thomas Holland. The subject of Sir Thomas's address will be "The Geography of Minerals". Further information can be obtained from the Clerk, Geographical Association, Municipal High School of Commerce, Princess Street, Manchester, 1.

THE annual meeting of the Institute of British Geographers will be held in the London School of Economics on January 5-6. Further information can be obtained from Mr. J. N. L. Baker, The University, Oxford.

THE twenty-seventh annual Conference of Educational Associations will be held at University College, London, W.C.I, on January 2-9, 1939, under the presidency of the Right Hon. Lord Macmillan. The subject of the presidential address will be "The Function of the University". A joint conference on "The University in a Changing World" will be held on January 5. Further information can be obtained from the Conference Secretary, Gordon House, 29 Gordon Square, W.C.1.

The Cambridge University Press is to publish shortly "Karl Pearson", a memoir consisting of two articles by his son. It surveys his life from his earliest days, giving extracts from letters to show the develop. ment of his philosophy, and details of his many activities. It is illustrated with many portraits, and there are appendixes summarizing his unpublished lectures and reports. 